CARING FOR PATIENTS 



\title{
Caring for Patients
}

\author{
$\infty \propto$
}

\section{A CRITIQUE OF THE MEDICAL MODEL}

\author{
Allen B. Barbour
}

Stanford University Press $\propto$ Stanford, California 


\section{Stanford University Press}

Stanford, California

(C) 1995 by the Board of Trustees of the Leland Stanford Junior University

Printed in the United States of America

CIP data are at the end of the book 
For Joan a 
